\title{
Novel method of lithium production from brines combining battery material and sodium sulphite as a cheap and environmentally friendly reducing agent
}

Sara Pérez-Rodríguez ${ }^{a}$, James Andy Milton ${ }^{b}$, Nuria Garcia-Araez ${ }^{a, *}$

a: Chemistry, University of Southampton, Highfield Campus, SO17 1BJ Southampton, UK

b: Ocean and Earth Science, National Oceanography Centre, University of

Southampton, SO14 3ZH Southampton, UK

*Corresponding author: n.garcia-araez@soton.ac.uk

\begin{abstract}
The growing increase in the global demand for lithium for the production of lithium batteries demands for the development of alternative, fast, environmental-friendly and cost-effective technologies for lithium production. Most lithium resources are in the form of brines, which are concentrated saline solutions containing lithium in the presence of an excess of other cations (primarily, sodium, magnesium and potassium). The use of lithium battery materials has been shown to be highly advantageous for the selective sequestration of lithium from brines, thus achieving the efficient separation of lithium from other cations and, with this, facilitating the production of the highly pure $\mathrm{Li}_{2} \mathrm{CO}_{3}$ required for the battery industry. The sequestration of lithium by battery material can be driven by electricity or redox agents, and the later has advantages in terms of the simplicity of the reactor design for large scale production. A critical aspect in the use of redox agents is the cost and environmental compatibility. Here we demonstrate the use of a novel redox reagent, sodium sulphite, that is cheap, non-toxic and induces fast lithium sequestration reactions.
\end{abstract}


Key words: lithium production, sodium sulphite, chemical lithium extraction, brines, lithiumion batteries, lithium iron phosphate.

\section{INTRODUCTION}

The demand for lithium production worldwide has experienced a dramatic increase in recent years, mainly due to the growth of the rechargeable lithium battery market, and an even higher increase is expected in coming years due to the expansion of lithium battery applications in electric vehicles, portable devices and grid storage. ${ }^{1-5}$ Consequently, the development of alternative methods of lithium production is urgently needed to cope with the increasing demands. ${ }^{6-9}$

Around $60 \%$ of the global lithium resources are in the form of highly saline solutions, called lithium brines, which contain cations such as $\mathrm{Na}^{+}, \mathrm{K}^{+}$and $\mathrm{Mg}^{2+}$ in much higher concentrations than that of $\mathrm{Li}^{+}{ }^{6,8}$ Unfortunately, current methods of lithium production can only be applied to a narrow range of brine compositions, ${ }^{6}$ and hence, it is necessary to develop new methods able to extract lithium ions selectively, in the presence of a vast excess of other cations, since that would enable a massive increase in the lithium production. Several methods for lithium sequestration from brines have been explored and the use of lithium battery materials to enable the selective lithium extraction from brines appears particularly promising, as illustrated in table 1. 
Table 1. Studies of lithium sequestration from brines using battery host materials.

\begin{tabular}{|c|c|c|c|c|c|}
\hline Battery material & $\begin{array}{l}\text { Methodology for } \\
\text { lithium recovery }\end{array}$ & Brine & Quantification of lithium sequestration & Experimental conditions & Ref. \\
\hline \multirow{11}{*}{$\mathrm{LiMn}_{2} \mathrm{O}_{4}$} & \multirow{11}{*}{ Electrochemical } & Geothermal water & Li uptake in solid $=11 \mathrm{mg} \mathrm{g}^{-1 \mathrm{a}}$ & $\begin{array}{l}10 \text { cycles of lithium capture (from } 1.0 \text { to } 0.2 \mathrm{~V}^{-} \mathrm{vs} \mathrm{SCE} \mathrm{SE}^{\mathrm{e}} \text { ) and release } \\
\text { (from } 0.2 \text { to } 1.0 \mathrm{~V} \text { vs. } \mathrm{SCE}^{\mathrm{e}} \text { ) at } 0.1 \mathrm{mV} \mathrm{s} \mathrm{s}^{-1} \text { using a } \mathrm{Pt} / \lambda-\mathrm{MnO}_{2} \\
\text { electrode and a Pt wire as counter electrode. }\end{array}$ & 10 \\
\hline & & Salar de Atacama & $\Delta\left[\mathrm{Li}^{+}\right]_{\text {recovery solution }}=18 \mathrm{mM}^{\mathrm{b}}$ & $\begin{array}{l}4 \text { cycles of lithium capture from brine (reduction) and release in } 1^{\text {st }} \\
\text { recovery solution (oxidation) followed by } 4 \text { cycles of lithium capture } \\
\text { from } 1^{\text {st }} \text { recovery solution (reduction) and release in } 2^{\text {nd }} \text { recovery } \\
\text { solution (oxidation) in a } \lambda-\mathrm{MnO}_{2} / \mathrm{Ag} \text { cell, } \pm 0.5 \mathrm{~mA} \mathrm{~cm}{ }^{-2}, 30 \text { min. }\end{array}$ & 11 \\
\hline & & Salar de Atacama & $\Delta\left[\mathrm{Li}^{+}\right]_{\text {recovery solution }}=60 \mathrm{mM}^{\mathrm{b}}$ & $\begin{array}{l}3 \text { cycles of lithium capture from brine (reduction) and release in } 1^{\text {st }} \\
\text { recovery solution (oxidation) followed by } 3 \text { cycles of lithium capture } \\
\text { from } 1^{\text {st }} \text { recovery solution (reduction) and release in } 2^{\text {nd }} \text { recovery } \\
\text { solution (oxidation) in a } \lambda-\mathrm{MnO}_{2} / \text { activated carbon cell, containing an } \\
\text { anion exchange membrane, } \pm 0.5 \mathrm{~mA} \mathrm{~cm} \text { ch }^{-2}, 30 \text { min. }\end{array}$ & 12 \\
\hline & & Salar de Atacama & $\Delta\left[\mathrm{Li}^{+}\right]_{\text {recovery solution }}=45 \mathrm{mM}^{\mathrm{b}}$ & $\begin{array}{l}3 \text { cycles of lithium capture (reduction, cut-off }=1.38 \mathrm{~V} \text { ) and release } \\
\text { (oxidation, cut-off }=1.93 \mathrm{~V} \text { ) in a } \lambda-\mathrm{MnO}_{2} / \mathrm{Zn} \text { cell containing an anion } \\
\text { exchange membrane, } \pm 0.5 \mathrm{~mA} \mathrm{~cm}{ }^{-2} .\end{array}$ & 13 \\
\hline & & Desalination brine & Li purity in recovery solution $=99 \%^{\mathrm{c}}$ & $\begin{array}{l}1 \text { cycle of lithium capture from brine }\left(-0.01 \mathrm{~mA} \mathrm{~cm}^{-2}\right) \text { and release in } \\
1^{\text {st }} \text { recovery solution }(0.2 \mathrm{~mA} \mathrm{~cm}-2) \text { followed by } 1 \text { cycle of lithium } \\
\text { capture from } 1^{\text {st }} \text { recovery solution }\left(-0.1 \mathrm{~mA} \mathrm{~cm}^{-2}\right) \text { and release in } 2^{\text {nd }} \\
\text { recovery solution }\left(0.1 \mathrm{~mA} \mathrm{c} \mathrm{m}^{-2}\right) \text { in a } \lambda-\mathrm{MnO}_{2} / \mathrm{Ag} \text { cell. Reduction } \\
\text { current cut-off }=0.2 \mathrm{~V} \text {. Oxidation current cut-off }=0.9 \text {. }\end{array}$ & 14 \\
\hline & & Salar de Olaroz & $\Delta\left[\mathrm{Li}^{+}\right]_{\text {recovery solution }}=16 \mathrm{mM}^{\mathrm{b}}$ & $\begin{array}{l}1 \text { cycle of lithium capture (reduction) and release (oxidation) in a } \lambda \text { - } \\
\mathrm{MnO}_{2} / \text { polypyrrole cell, } \pm 2.5 \mathrm{~mA} \mathrm{~cm}-2,16 \mathrm{~h} \text {. }\end{array}$ & 15 \\
\hline & & Salar de Atacama & $\begin{array}{l}\text { Li purity recovery solution }=61 \%(\lambda- \\
\left.\mathrm{MnO}_{2} / \mathrm{NiHCF}\right), 96 \%\left(\lambda-\mathrm{MnO}_{2} / \mathrm{Ag}\right)^{\mathrm{c}}\end{array}$ & $\begin{array}{l}1 \text { cycle of lithium capture (reduction) and release (oxidation) in a } \lambda- \\
\mathrm{MnO}_{2} / \mathrm{NiHCF} \text { or } \lambda-\mathrm{MnO}_{2} / \mathrm{Ag} \text { cell, } \pm 148 \mathrm{~mA} \mathrm{~g}^{-1}, 60 \mathrm{~min} \text {. }\end{array}$ & 16 \\
\hline & & Salt lake brine & Li uptake in solid $=35 \mathrm{mg} \mathrm{g}^{-1 \mathrm{a}}$ & $\begin{array}{l}1 \text { cycle of lithium capture (reduction, }-0.2 \mathrm{~V} \text { vs } \mathrm{Ag} / \mathrm{AgCl}) \text { and release } \\
(\text { oxidation, } 1 \mathrm{~V} \text { vs } \mathrm{Ag} / \mathrm{AgCl}) \text {, each step for } 2 \mathrm{~h} \text { using a } \lambda \text { - } \\
\mathrm{MnO}_{2} / \text { polypyrrole/polyninylsulfonate electrode and a Pt wire as } \\
\text { counter electrode. }\end{array}$ & 17 \\
\hline & & $\begin{array}{l}\text { Simulated brine } \\
\text { concentrated seawater }\end{array}$ & $\mathrm{Li}$ uptake in solid $=21-22 \mathrm{mg} \mathrm{g}^{-1 \text { a }}$ & $\begin{array}{l}1 \text { cycle of lithium capture (reduction, at }-0.6 \mathrm{~V} \text { ) and release } \\
\text { (oxidation, at } 0.6 \mathrm{~V} \text { ), each step for } 120 \text { min, in a } \mathrm{LiMn} \mathrm{O}_{4} / \mathrm{Li}_{1-\mathrm{x}} \mathrm{Mn}_{2} \mathrm{O}_{4} \\
\text { cell containing an anion exchange membrane. }\end{array}$ & 18 \\
\hline & & Salt lake brine & $\begin{array}{l}\Delta\left[\mathrm{Li}^{+}\right]_{\text {recovery solution }}=18 \mathrm{mM} \text { (film electrode) } \\
25 \mathrm{mM} \text { (powder electrode) }{ }^{\mathrm{b}}\end{array}$ & $\begin{array}{l}100 \text { cycles of lithium capture (reduction) and release (oxidation) in a } \\
\lambda-\mathrm{MnO}_{2} / \mathrm{Ag} \text { cell, } \pm 50 \mathrm{~mA} \mathrm{~g}{ }^{-1}, 30 \text { min. }\end{array}$ & 19 \\
\hline & & Taijinair lake & $\Delta\left[\mathrm{Li}^{+}\right]_{\text {recovery solution }}=35 \mathrm{mM}^{\mathrm{b}}$ & 4 cycles of lithium capture (reduction, cut-off $=0.15 \mathrm{~V}$ ) and release & 20 \\
\hline
\end{tabular}




\begin{tabular}{|c|c|c|c|c|c|}
\hline & \multirow{8}{*}{ 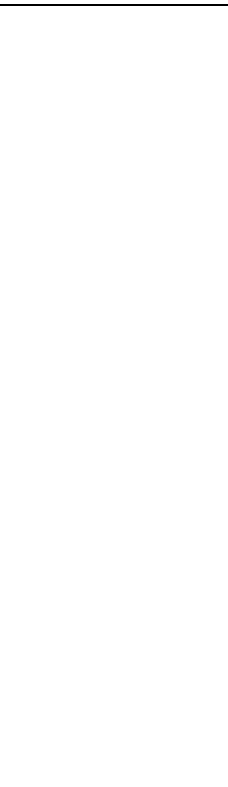 } & \multirow[b]{2}{*}{ Salt lake brine } & \multirow[b]{2}{*}{ Li uptake in solid $=14 \mathrm{mg} \mathrm{g}^{-1 \mathrm{a}}$} & $\begin{array}{l}\text { (oxidation, cut-off }=0.7 \mathrm{~V} \text { ) in a polyaniline } / \mathrm{Li}_{\mathrm{x}} \mathrm{Mn}_{2} \mathrm{O}_{4} \text { cell, } \pm 0.5 \mathrm{~mA} \\
\mathrm{~cm}^{-2} \text {. }\end{array}$ & \multirow[b]{2}{*}{21} \\
\hline & & & & $\begin{array}{l}5 \text { cycles of lithium capture (reduction) and release (oxidation) in a } \lambda \text { - } \\
\mathrm{MnO}_{2} / \mathrm{Ag}^{-} \text {cell, } \pm 50 \mathrm{~mA} \mathrm{~g}^{-1}, 30 \mathrm{~min} \text {. }\end{array}$ & \\
\hline \multirow{6}{*}{$\mathrm{LiFePO}_{4}$} & & Sodium rich brine & $\begin{array}{c}\text { Li uptake in solid }=8 \mathrm{mg} \mathrm{g}^{-1 \mathrm{a}} \\
\text { Li purity in recovery solution }=85 \%\end{array}$ & $\begin{array}{l}1 \text { cycle of lithium capture (reduction) and release (oxidation) in a } \lambda \text { - } \\
\mathrm{MnO}_{2} / \mathrm{Ag} \text { cell, } \pm 0.5 \mathrm{~mA} \mathrm{~cm}{ }^{-2}, 120 \mathrm{~min} \text {. }\end{array}$ & 22 \\
\hline & & Salar de Atacama & Li purity in recovery solution $=98 \%^{\mathrm{c}}$ & $\begin{array}{l}1 \text { cycle of lithium capture (reduction) and release (oxidation) in a } \lambda \text { - } \\
\mathrm{MnO}_{2} / \mathrm{Ag} \text { cell, } \pm 0.5 \mathrm{~mA} \mathrm{~cm} \mathrm{~cm}^{-2}, 60 \mathrm{~min} \text {. }\end{array}$ & 23 \\
\hline & & Salar de Atacama & Li purity in recovery solution $=74 \%^{\mathrm{c}}$ & $\begin{array}{l}1 \text { cycle of lithium capture (reduction) and release (oxidation) in a } \lambda \text { - } \\
\mathrm{MnO}_{2} / \mathrm{NiHCF}, \pm 108.5 \mathrm{~mA} \mathrm{~g}^{-1}, 40 \mathrm{~min} \text {. }\end{array}$ & 24 \\
\hline & & West Taijnar salt lake & Li uptake in solid $=29-33 \mathrm{mg} \mathrm{g}^{-1}$ a & $\begin{array}{l}1 \text { cycle of lithium capture (reduction, at }-1 \mathrm{~V} \text { ) and release (oxidation, } \\
\text { at } 1 \mathrm{~V} \text { ), each step for } 10 \mathrm{~h} \text {, in a } \mathrm{LiFePO}_{4} / \mathrm{FePO}_{4} \text { cell containing an } \\
\text { anion exchange membrane. }\end{array}$ & 25 \\
\hline & & Salt lake brine & Li uptake in solid $=39 \mathrm{mg} \mathrm{g}^{-1 \mathrm{a}}$ & $\begin{array}{l}1 \text { cycle of lithium capture (reduction, at }-0.25 \mathrm{~V} \text { ) and release } \\
\text { (oxidation, at } 0.25 \mathrm{~V} \text { ), each step for } 10 \mathrm{~h} \text {, in a } \mathrm{LiFePO}_{4} / \mathrm{FePO}_{4} \text { cell } \\
\text { containing an anion exchange membrane. }\end{array}$ & 26 \\
\hline & & West Taijnar salt lake & $\mathrm{Li}$ uptake in solid $=25 \mathrm{mg} \mathrm{g}^{-1 \mathrm{a}}$ & $\begin{array}{l}1 \text { cycle of lithium capture (reduction, at }-0.2 \mathrm{~V} \text { ) and release } \\
\text { (oxidation, at } 0.2 \mathrm{~V} \text { ), each step limited to a current cut-off }=0.05 \mathrm{~mA} \\
\mathrm{~cm}^{-2} \text {, in a } \mathrm{LiFePO}_{4} / \mathrm{FePO}_{4} \text { cell containing an anion exchange } \\
\text { membrane. }\end{array}$ & 27 \\
\hline $\mathrm{LiNi}_{1 / 3} \mathrm{Co}_{1 / 3} \mathrm{Mn}_{1 / 3} \mathrm{O}_{2}$ & & Salar de Uyuni & $\begin{array}{c}\text { Li uptake in solid }=11 \mathrm{mg} \mathrm{g}^{-1 \mathrm{a}} \\
\text { Li purity in recovery solution }=97 \%{ }^{\mathrm{c}}\end{array}$ & $\begin{array}{l}1 \text { cycle of lithium capture (reduction) and release (oxidation) in a } \mathrm{Li}_{1-} \\
\mathrm{Ni}_{1 / 3} \mathrm{Co}_{1 / 3} \mathrm{Mn}_{1 / 3} \mathrm{O}_{2} / \mathrm{Ag} \text { cell, } \pm 0.5 \mathrm{~mA} \mathrm{~cm} \\
\end{array}$ & 28 \\
\hline $\mathrm{LiNi}_{0.5} \mathrm{Co}_{1.5} \mathrm{Mn}_{1.5} \mathrm{O}_{2}$ & & Salar de Uyuni & $\begin{array}{l}\text { Li uptake in solid }=9 \mathrm{mg} \mathrm{g}^{-1 \mathrm{a}} \\
\text { Li purity in recovery solution }=98 \%{ }^{\mathrm{c}}\end{array}$ & $\begin{array}{l}1 \text { cycle of lithium capture (reduction) and release (oxidation) in a } \mathrm{Li}_{1-} \\
{ }_{x} \mathrm{Ni}_{0.5} \mathrm{Co}_{1.5} \mathrm{Mn}_{1.5} \mathrm{O}_{2} / \mathrm{Ag} \text { cell, } \pm 0.44 \mathrm{~mA} \mathrm{~cm}{ }^{-2}, 20 \mathrm{~min} \text {. }\end{array}$ & 29 \\
\hline \multirow[b]{2}{*}{$\mathrm{LiFePO}_{4}$} & \multirow[b]{2}{*}{ Redox agents } & Central Altiplano & Li uptake in solid $=46 \mathrm{mg} \mathrm{g}^{-1 \mathrm{a}}$ & $\mathrm{Na}_{2} \mathrm{~S}_{2} \mathrm{O}_{3}$ as reducing agent, $\left[\mathrm{Na}_{2} \mathrm{~S}_{2} \mathrm{O}_{3}\right]=0.3 \mathrm{M}, 24 \mathrm{~h}$ & 30 \\
\hline & & Central Altiplano & $\begin{array}{l}\text { Li uptake in solid }=44-45 \mathrm{mg} \mathrm{g}^{-1 \mathrm{a}} \\
\text { Li purity in solid }=94-96 \% \mathrm{~d}^{\mathrm{d}}\end{array}$ & $\mathrm{Na}_{2} \mathrm{SO}_{3}$ as reducing agent, $\left[\mathrm{Na}_{2} \mathrm{SO}_{3}\right]=0.3 \mathrm{M}, 24 \mathrm{~h}$. & $\begin{array}{l}\text { This } \\
\text { work }\end{array}$ \\
\hline
\end{tabular}

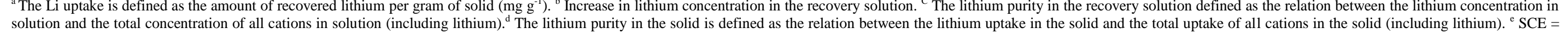
Saturated calomel Electrode. 
Within the methods using battery materials, the use of redox agents to induce the reaction is particularly well suited to be scaled-up for industrial lithium production. We first demonstrated the suitability of the use of redox agents combined with battery materials by employing sodium thiosulfate $\left(\mathrm{Na}_{2} \mathrm{~S}_{2} \mathrm{O}_{3}\right)$ to drive the lithium sequestration reaction into a $\mathrm{FePO}_{4}$ host battery structure, thus producing $\mathrm{LiFePO}_{4}$ as the reaction product. ${ }^{30}$ As illustrated in figure 1, once lithium is selectively sequestrated in the battery host structure (in the form of $\mathrm{LiFePO}_{4}$ ), then the $\mathrm{LiFePO}_{4}$ powder is removed from the reaction mixture, and lithium is released using an oxidising agent thus recovering the battery material (as $\mathrm{FePO}_{4}$ ) and producing a lithium salt (e.g. $\mathrm{Li}_{2} \mathrm{CO}_{3}$ ) as the overall product of the whole process. Therefore, the battery material can be used in many cycles of lithium sequestration and release, and only the redox agents are consumed for the production of the lithium salt. In this work, we report the use of an advantageous alternative redox agent, sodium sulfite $\left(\mathrm{Na}_{2} \mathrm{SO}_{3}\right)$, which is cheaper, induces a higher amount of lithium insertion per mole of reactant, is non-toxic and the product of the reaction $\left(\mathrm{Na}_{2} \mathrm{SO}_{4}\right)$ is completely inert. The reactions of lithium sequestration are as follows:

$$
\begin{array}{ll}
\mathrm{Li}^{+}+\mathrm{FePO}_{4}+\mathrm{e}^{-} \rightleftharpoons \mathrm{LiFePO}_{4} & \left(E^{0}=0.40 \mathrm{~V} \text { vs. SHE }\right)^{30} \\
2 \mathrm{~S}_{2} \mathrm{O}_{3}{ }^{2-} \rightleftharpoons \mathrm{S}_{4} \mathrm{O}_{6}{ }^{2-}+2 \mathrm{e}^{-} & \left(E^{0}=0.08 \mathrm{~V} \text { vs. SHE }\right)^{31} \\
2 \mathrm{Li}^{+}+2 \mathrm{FePO}_{4}+2 \mathrm{~S}_{2} \mathrm{O}_{3}{ }^{2-} \rightleftharpoons 2 \mathrm{LiFePO}_{4}+\mathrm{S}_{4} \mathrm{O}_{6}{ }^{2-} \quad\left(\Delta G^{0}=-62 \mathrm{~kJ} / \mathrm{mol}\right) \\
\mathrm{SO}_{3}{ }^{2-}+\mathrm{H}_{2} \mathrm{O} \rightleftharpoons \mathrm{SO}_{4}{ }^{2-}+2 \mathrm{H}^{+}+2 \mathrm{e}^{-} & \left(E^{0}=-0.52 \mathrm{~V} \text { vs. SHE}, \mathrm{pH}=7\right)^{31} \\
2 \mathrm{Li}^{+}+2 \mathrm{FePO}_{4}+\mathrm{SO}_{3}{ }^{2-}+\mathrm{H}_{2} \mathrm{O} \rightleftharpoons 2 \mathrm{LiFePO}_{4}+\mathrm{SO}_{4}{ }^{2-}+2 \mathrm{H}^{+}\left(\Delta G^{0}=-178 \mathrm{~kJ} / \mathrm{mol}\right)
\end{array}
$$

where $E^{0}$ stands for the standard potentials and the driving force for the lithium sequestration reactions are the lower values of standard potentials of the reducing agents $\left(\mathrm{Na}_{2} \mathrm{~S}_{2} \mathrm{O}_{3}\right.$ and $\mathrm{Na}_{2} \mathrm{SO}_{3}$ ) compared to the $\mathrm{LiFePO} / \mathrm{FePO}_{4}$ redox potential.

$\mathrm{Na}_{2} \mathrm{SO}_{3}$ is a cheap and accessible reagent used in different applications, such as pulp and paper industry, ${ }^{32}$ water treatment ${ }^{33}$ or in the textile industry. ${ }^{34}$ Additionally, it is also used in 
chemical manufacturing as a sulfonation agent and in the production of $\mathrm{Na}_{2} \mathrm{~S}_{2} \mathrm{O}_{3} \cdot{ }^{35} \mathrm{Na}_{2} \mathrm{SO}_{3}$ has also been proposed as a cost-effective alternative for battery recycling. ${ }^{36,37}$ On the other hand, the use of $\mathrm{Na}_{2} \mathrm{SO}_{3}$ instead of $\mathrm{Na}_{2} \mathrm{~S}_{2} \mathrm{O}_{3}$ seems to be favourable considering the stoichiometry of the reactions (reactions 3 and 5). Indeed, reaction 5 has a stoichiometric molar ratio $\mathrm{Li}^{+} / \mathrm{Na}_{2} \mathrm{SO}_{3}=2 / 1$, while the stoichiometric molar ratio of $\mathrm{Li}^{+} / \mathrm{Na}_{2} \mathrm{~S}_{2} \mathrm{O}_{3}=1 / 1$ suggests that a higher amount of reducing agent would be required to induce the $\mathrm{Li}$ intercalation using $\mathrm{Na}_{2} \mathrm{~S}_{2} \mathrm{O}_{3}$ (reaction 3). Additionally, the reaction product of the sequestration reaction induced by $\mathrm{Na}_{2} \mathrm{SO}_{3}$ is $\mathrm{Na}_{2} \mathrm{SO}_{4}$, which is inert and innocuous, and $\mathrm{Na}_{2} \mathrm{SO}_{3}$ itself is also non-toxic. ${ }^{38}$ In this work, the use of $\mathrm{Na}_{2} \mathrm{SO}_{3}$ to induce the sequestration of lithium into a $\mathrm{FePO}_{4}$ host structure is fully characterised and compared with the use of $\mathrm{Na}_{2} \mathrm{~S}_{2} \mathrm{O}_{3}$, concluding that the selectivity and kinetics of lithium sequestration reactions are similar with both reagents, thus confirming the suitability of $\mathrm{Na}_{2} \mathrm{SO}_{3}$ as an advantageous alternative reagent for the production of lithium from brines.

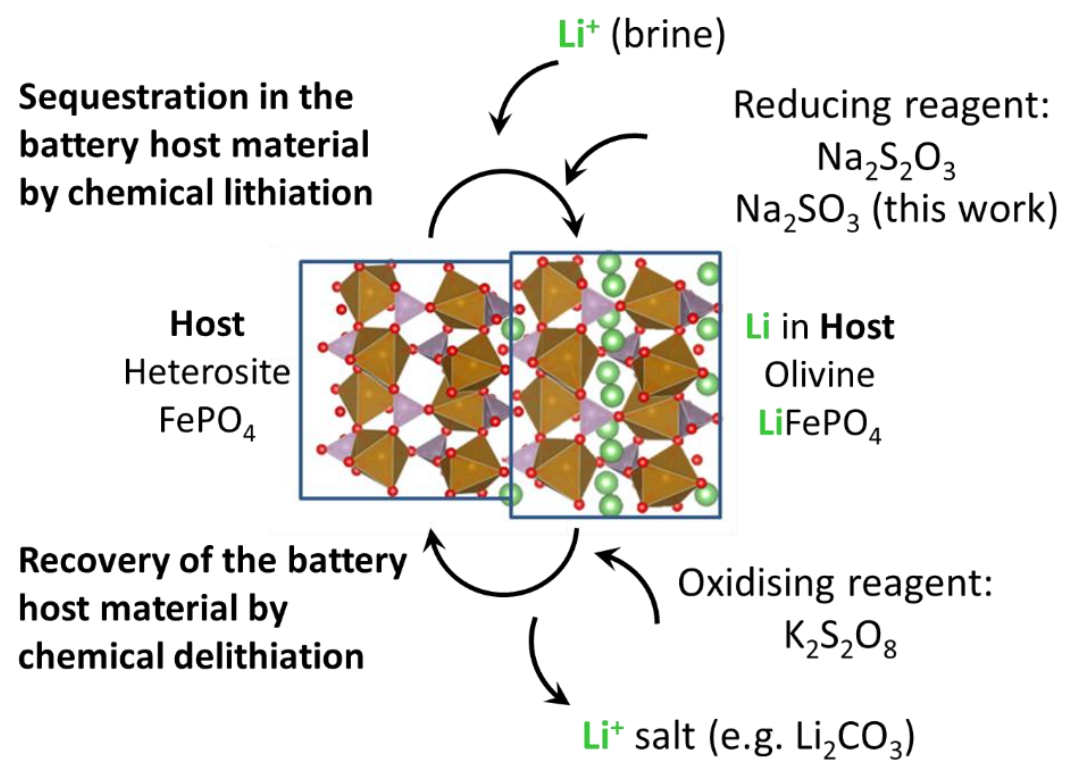

Figure 1. Methodology for the production of lithium using $\mathrm{LiFePO}_{4}$ battery material as sequestering agent and redox reagents to drive the reactions. 


\section{MATERIALS AND METHODS}

\section{Chemical delithiation of lithium iron phospate}

Commercial $\mathrm{LiFePO}_{4}$ (LFP, provided by Tatung, battery grade) was used for all the experiments. $\mathrm{LiFePO}_{4}$ was chemically delithiated using $\mathrm{K}_{2} \mathrm{~S}_{2} \mathrm{O}_{8}$ (Sigma Aldrich, ACS grade, $\geq 99 \%$ ) as an oxidizing agent following the methodology reported previously. ${ }^{30,39}$ Briefly, $\mathrm{LiFePO}_{4}(0.2 \mathrm{M})$ and $\mathrm{K}_{2} \mathrm{~S}_{2} \mathrm{O}_{8}(0.1 \mathrm{M})$ were mixed in ultrapure water $(18.2 \mathrm{M} \Omega \mathrm{cm}$, Suez, Select). The reaction was held for 24 hours at room temperature under continuous stirring. The resultant solid was filtered, washed and dried overnight at $80^{\circ} \mathrm{C}$. These conditions led to the complete delithiation of $\mathrm{LiFePO}_{4}(\mathrm{LFP})$, obtaining $\mathrm{FePO}_{4}(\mathrm{FP})$ as the reaction product. ${ }^{30,39}$

\section{Chemical lithiation of iron phospate}

Delithiated $\mathrm{LiFePO}_{4}\left(\mathrm{FePO}_{4}\right.$ or $\mathrm{FP}$, obtained as described above) was chemically lithiated using $\mathrm{Na}_{2} \mathrm{~S}_{2} \mathrm{O}_{3}\left(\mathrm{Na}_{2} \mathrm{~S}_{2} \mathrm{O}_{3} \cdot 5 \mathrm{H}_{2} \mathrm{O}\right.$, Sigma Aldrich, ACS grade, $\left.\geq 99.5 \%\right)$ or $\mathrm{Na}_{2} \mathrm{SO}_{3}($ Sigma Aldrich, ACS grade, $\geq 98 \%)$ as reducing agents and $\mathrm{Li}_{2} \mathrm{SO}_{4}\left(\mathrm{Li}_{2} \mathrm{SO}_{4} \cdot \mathrm{H}_{2} \mathrm{O}\right.$, Sigma Aldrich, ACS grade, $\geq 99 \%$ ) as the lithium source. In a typical experiment, a known amount of $\mathrm{FePO}_{4}$ (around $1 \mathrm{~g}$ ), the reducing agent $\left(\mathrm{Na}_{2} \mathrm{~S}_{2} \mathrm{O}_{3}\right.$ or $\left.\mathrm{Na}_{2} \mathrm{SO}_{3}\right)$ and $\mathrm{Li}_{2} \mathrm{SO}_{4}$ were dissolved in $35 \mathrm{~mL}$ of ultrapure water under continuous stirring at room temperature. The initial molar concentrations of the reagents in the mixture were $0.375 \mathrm{M} \mathrm{FePO}_{4}, 0.75 \mathrm{M} \mathrm{Li}_{2} \mathrm{SO}_{4}$ and $1.5 \mathrm{M}$ $\mathrm{Na}_{2} \mathrm{~S}_{2} \mathrm{O}_{3}$ or $\mathrm{Na}_{2} \mathrm{SO}_{3}$. Thus, the molar ratio of $\mathrm{FePO}_{4}: \mathrm{Li}^{+}$: reducing agent in the initial mixture was 1:4:4. The reaction was stopped after $20 \mathrm{~min}, 1$ hour or 24 hours. The resultant solid was filtered, washed and dried overnight at $80^{\circ} \mathrm{C}$. The solid reaction product was characterized by XRD, galvanostatic cycling in Li-half cells, and ICP measurements of the digested solid.

\section{Chemical extraction of lithium from artificial brines}

Chemical extraction of lithium was also performed in two different artificial brines. The molar compositions are listed in Table 2. These experiments were carried out in the presence of $0.3 \mathrm{M} \mathrm{Na}_{2} \mathrm{SO}_{3}$. For brine 1, $0.03 \mathrm{M} \mathrm{FePO}_{4}$ was employed, and for brine 2, $0.1 \mathrm{M} \mathrm{FePO}_{4}$. 
Therefore, the molar ratio of $\mathrm{FePO}_{4}: \mathrm{Li}^{+}$: reducing agent in the initial mixture was $1: 2: 10$ for brine 1 and 1:2:3 for brine 2. These initial compositions were selected so that, throughout the process of lithium sequestration, lithium ions and the reducing agent are both in excess with respect to $\mathrm{FePO}_{4}$ for both brine compositions. The reactions were carried out at room temperature for $24 \mathrm{~h}$. The solid reaction product was characterized by XRD, galvanostatic cycling in Li-half cells, and ICP measurements of the digested solid.

Chloride salts, $\mathrm{LiCl}, \mathrm{NaCl}, \mathrm{KCl}$ and $\mathrm{MgCl}_{2} \cdot 6 \mathrm{H}_{2} \mathrm{O}$ (Sigma Aldrich, ACS grade, $\geq 99 \%$ ), were used for the preparation of the brines with the exception of the potassium source in brine 2, where $\mathrm{K}_{2} \mathrm{SO}_{4}$ (Sigma Aldrich, 99\%) was used. These artificial brines represent two typical compositions in the lithium reserves in Central Altiplano (Bolivia), ${ }^{40}$ and they were used in our previous study using $\mathrm{Na}_{2} \mathrm{~S}_{2} \mathrm{O}_{3}$ as reducing agent. ${ }^{30}$

Table 2. Molar compositions of the artificial brines studied in this work.

\begin{tabular}{|c|c|c|c|c|c|}
\hline Brine & $\mathbf{L i C l}$ & $\mathbf{N a C l}$ & $\mathbf{K C l}$ & $\mathbf{K}_{\mathbf{2}} \mathbf{S O}_{\mathbf{4}}$ & $\mathbf{M g C l}_{\mathbf{2}}$ \\
\hline 1 & $0.06 \mathrm{M}$ & $4.0 \mathrm{M}$ & $0.2 \mathrm{M}$ & - & $0.3 \mathrm{M}$ \\
\hline 2 & $0.2 \mathrm{M}$ & $2.4 \mathrm{M}$ & - & $0.3 \mathrm{M}$ & $1.3 \mathrm{M}$ \\
\hline
\end{tabular}

\section{X-ray diffraction characterization}

X-ray diffraction (XRD) patterns of the materials were recorded using a Bruker D2 Phaser diffractometer equipped with a $300 \mathrm{~W}(30 \mathrm{kV}-10 \mathrm{~mA}) \mathrm{Cu} \mathrm{K} \alpha$ radiation source with a BraggBrentano configuration. Scans were done at $5.3^{\circ} \mathrm{min}^{-1}$ for $2 \theta$ values from $10^{\circ}$ to $50^{\circ}$.

\section{Electrochemical characterisation in Li-half cells}

$\mathrm{Li}_{\mathrm{x}} \mathrm{FePO}_{4}$ electrodes were prepared by mixing the active material $\left(\mathrm{LiFePO}_{4}\right.$ as received or as obtained from the lithiation reaction of $\mathrm{FePO}_{4}$ ), carbon black (Timcal SUPER C65) and polyvinylidene fluoride (PVDF, Solef® 5130) in a weight ratio of 80:10:10. Slurry inks were prepared using N-methyl-2-pyrrolidone (NMP) as solvent. The slurry was mixed under 2000 rpm for 5 minutes with a planetary mixer (THINKY ARE-250). This last process (2000 rpm 
for 5 minutes) was repeated three times to obtain a homogeneous mixture. Subsequently, the resultant slurry was hand coated on an aluminum foil (Advent Research Materials, thickness = $0.125 \mathrm{~mm}, 99 \%$ ) with a K-bar to a wet thickness of $200 \mu \mathrm{m}$. Prior to the coating, the aluminum foil was roughened with a P1200 sandpaper to improve adhesion. The electrodes were dried in a vacuum oven at $80^{\circ} \mathrm{C}$ overnight and then, punched (precision punch, Nogami) with a $11 \mathrm{~mm}$ diameter die and calendaring to 10 tonnes (Specac). The active material mass loading was $\approx 3-4 \mathrm{mg} \mathrm{cm}^{-2}$.

The electrochemical tests were performed in PFA Swagellok® type cells, previously dried at $80^{\circ} \mathrm{C}$ overnight. The cells were assembled in an argon glove box $\left(\leq 0.1 \mathrm{ppm} \mathrm{H}_{2} \mathrm{O} ; \leq 0.1 \mathrm{ppm}\right.$ $\mathrm{O}_{2}$ ), using the $\mathrm{Li}_{x} \mathrm{FePO}_{4}$ electrodes as working electrodes and a lithium foil (Rockwood Lithium, $100 \mu \mathrm{m}$ thickness, cut in $12 \mathrm{~mm}$ diameter discs) as both counter and reference electrode. The electrolyte was $150 \mu \mathrm{L}$ of $1.0 \mathrm{M}$ lithium hexafluorophosphate solution $\left(\mathrm{LiPF}_{6}\right)$ in ethylene carbonate (EC) and dimethyl carbonate DMC with a volume ratio $\mathrm{EC} / \mathrm{DMC}=1 / 1$ (LP57, PuriEL). Two glass fibers (Whatman ${ }^{\circledR}$, grade GF-F, $12 \mathrm{~mm}$ diameter) were used as separators. Aluminium current collectors were used for the $\mathrm{Li}_{x} \mathrm{FePO}_{4}$ electrodes, whereas copper collectors were used on the lithium side. $\mathrm{Li}_{\mathrm{x}} \mathrm{FePO}_{4}$ electrodes and GF-F separators were dried under vacuum at $120^{\circ} \mathrm{C}$ for 48 hours in a Büchi tube oven before being introduced in the glovebox.

The cells were placed in a Memmert climatic chamber set to $25{ }^{\circ} \mathrm{C}$ and electrochemical measurements were done with a VMP2 multichannel potentiostat (BioLogic). Galvanostatic

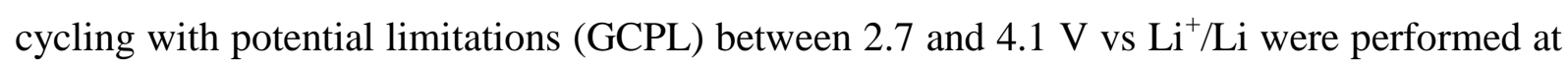
a C-rate of $\mathrm{C} / 10$ corresponding to a specific current (normalized by the mass of $\mathrm{Li}_{\mathrm{x}} \mathrm{FePO}_{4}$ active material) of $17 \mathrm{mAh} \mathrm{g}^{-1}$. 


\section{Inductively coupled plasma mass spectrometry (ICP-MS)}

ICP-MS analysis were performed on a Thermo Scientific X-Series II spectrometer to determine the amounts of $\mathrm{Li}^{+}, \mathrm{Na}^{+}, \mathrm{K}^{+}$and $\mathrm{Mg}^{2+}$ present in the $\mathrm{Li}_{\mathrm{x}} \mathrm{FePO}_{4}$ solids. Samples were digested in $2 \mathrm{ml}$ of a solution of $20 \mathrm{wt} \%$ of $\mathrm{HCl}$ (Sigma Aldrich, ACS grade, 37\%) and 20 wt.\% $\mathrm{HNO}_{3}$ (Sigma Aldrich, ACS grade, 70\%) in ultrapure water $(18.2 \mathrm{M} \Omega \mathrm{cm}$, Suez, Select). The mixture was stirred at $60^{\circ} \mathrm{C}$ for 2 hours. PFA volumetric flasks with screw caps were used for the digestions. The flask and stirrer were washed with ultrapure water previously to each experiment.

\section{RESULTS AND DISCUSSION}

\section{Kinetics of lithium sequestration by $\mathrm{FePO}_{4}$ induced by $\mathrm{Na}_{2} \mathrm{SO}_{3}$ or $\mathrm{Na}_{2} \mathrm{~S}_{2} \mathrm{O}_{4}$}

The reaction of sequestration of lithium onto a $\mathrm{FePO}_{4}$ battery host driven by $\mathrm{Na}_{2} \mathrm{SO}_{3}$ (reaction 5) or $\mathrm{Na}_{2} \mathrm{~S}_{2} \mathrm{O}_{3}$ (reaction 3) produces $\mathrm{LiFePO}_{4}$ as a reaction product. The reaction was characterised by mixing $\mathrm{FePO}_{4}$ power (FP, as obtained after de-lithiation of $\mathrm{LiFePO}_{4}, \mathrm{LFP}$ ), the reducing agent $\left(\mathrm{Na}_{2} \mathrm{SO}_{3}\right.$ or $\left.\mathrm{Na}_{2} \mathrm{~S}_{2} \mathrm{O}_{3}\right)$ and a lithium salt $\left(\mathrm{Li}_{2} \mathrm{SO}_{4}\right)$, with initial concentrations of $0.375 \mathrm{M} \mathrm{FePO}_{4}, 1.5 \mathrm{M} \mathrm{Na}_{2} \mathrm{SO}_{3}$ or $\mathrm{Na}_{2} \mathrm{~S}_{2} \mathrm{O}_{3}$ and $0.75 \mathrm{M} \mathrm{Li}_{2} \mathrm{SO}_{4}$. Under these conditions, the initial concentration of reducing agent and $\mathrm{Li}^{+}$are 4 times higher than that of $\mathrm{FePO}_{4}$, thus ensuring that the reaction of lithium sequestration does not produce a significant change in the concentrations of reducing agent and $\mathrm{Li}^{+}$, while enabling the full conversion of $\mathrm{FePO}_{4}$ into $\mathrm{LiFePO}_{4}$. The reaction was stopped after 20 minutes, 1 hour or 24 hours, and the solid powder reaction product was filtered, dried and characterised by XRD, electrochemical measurements in Li-half cells and ICP measurements of the digested solid. Table 3 shows the result of the evaluation of the lithium molar content on the $\mathrm{Li}_{\mathrm{x}} \mathrm{FePO}_{4}$ powder sample using these three techniques. The kinetics of the lithium sequestration reaction are fast, since almost full lithiation is achieved in one hour for both reducing agents. 
Table 3. Lithium molar content, $x$, of $\mathrm{Li}_{x} \mathrm{FePO}_{4}$ samples obtained by lithiation of $\mathrm{FePO}_{4}$ from the reaction product of $0.375 \mathrm{M} \mathrm{FePO}_{4}+0.75 \mathrm{M} \mathrm{Li}_{2} \mathrm{SO}_{4}+1.5 \mathrm{M} \mathrm{Na}_{2} \mathrm{~S}_{2} \mathrm{O}_{3}$ or $\mathrm{Na}_{2} \mathrm{SO}_{3}$ after different reaction times, as indicated, as estimated from ICP (a), electrochemical (b) and XRD (c) measurements.

\begin{tabular}{|c|c|c|c|}
\hline $\begin{array}{c}\text { Reducing } \\
\text { agent }\end{array}$ & $\mathbf{2 0}$ min & $\mathbf{1 ~ h}$ & $\mathbf{2 4} \mathbf{~ h}$ \\
\hline $\mathrm{Na}_{2} \mathrm{~S}_{2} \mathrm{O}_{3}$ & $0.29^{\mathrm{a}}$ & & \\
ref. $^{30}$ & $0.25^{\mathrm{b}}$ & $0.86^{\mathrm{b}}$ & $1.02^{\mathrm{b}}$ \\
& $0.22^{\mathrm{c}}$ & $1.00^{\mathrm{c}}$ & $1.00^{\mathrm{c}}$ \\
\hline & $0.78^{\mathrm{a}}$ & $0.92^{\mathrm{a}}$ & $0.98^{\mathrm{a}}$ \\
$\mathrm{Na}_{2} \mathrm{SO}_{3}$ & $0.74^{\mathrm{b}}$ & $0.90^{\mathrm{b}}$ & $1.00^{\mathrm{b}}$ \\
& & $1.00^{\mathrm{c}}$ & $1.00^{\mathrm{c}}$ \\
\hline
\end{tabular}

Figure 2 shows some examples of the XRD characterisation, illustrating that nearly full conversion to $\mathrm{LiFePO}_{4}$ is obtained with both reducing reagents after 1 hour of reaction time, since the characteristic diffraction peaks associated to $\mathrm{FePO}_{4}$ have fully disappeared and the diffraction peaks associated to $\mathrm{LiFePO}_{4}$ have appeared after the reaction. ${ }^{30}$ 


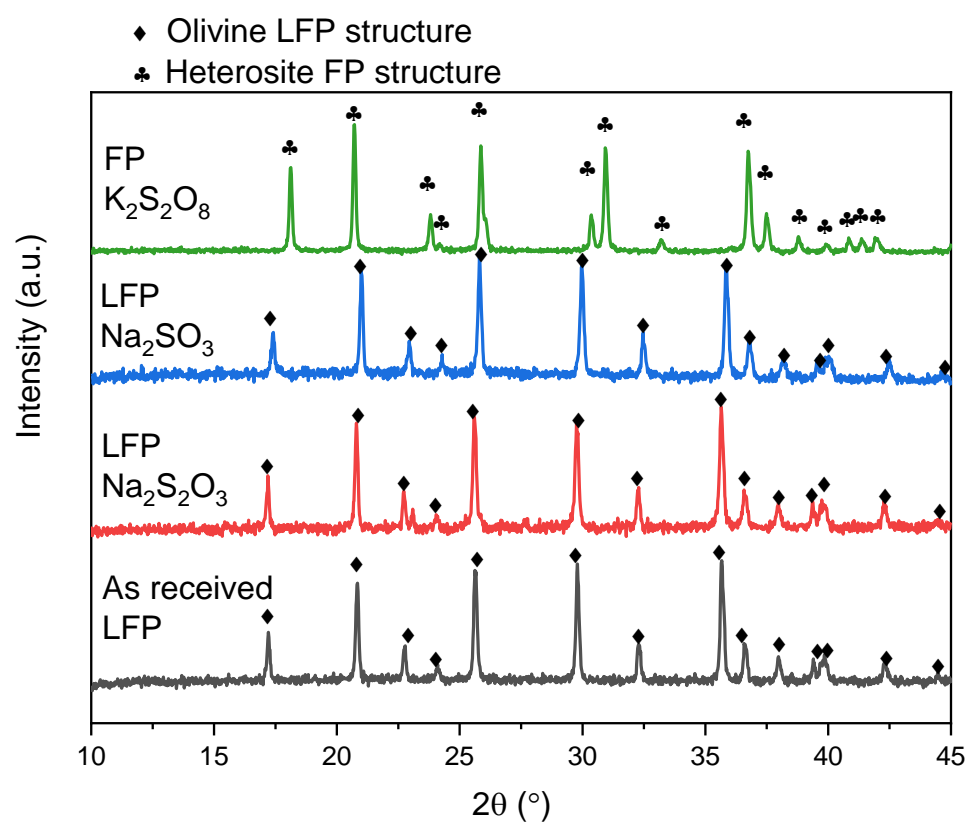

Figure 2. XRD patterns of the $\mathrm{Li}_{\mathrm{X}} \mathrm{FePO} 4$ solid powders obtained from the reaction product of $0.375 \mathrm{M} \mathrm{FePO}_{4}+0.75 \mathrm{M} \mathrm{Li}_{2} \mathrm{SO}_{4}+1.5 \mathrm{M} \mathrm{Na}_{2} \mathrm{~S}_{2} \mathrm{O}_{3}$ or $\mathrm{Na}_{2} \mathrm{SO}_{3}$ after 1 hour of reaction time. The diffractograms of the as received $\mathrm{LiFePO}_{4}(\mathrm{LFP})$ powder and of $\mathrm{FePO}_{4}(\mathrm{FP})$ obtained from chemical delithiation of LFP using $\mathrm{K}_{2} \mathrm{~S}_{2} \mathrm{O}_{8}$ are also shown for comparison.

Electrochemical testing in Li-half cell cells was also performed to quantify the extent of lithium insertion into the $\mathrm{FePO}_{4}$ host. For that purpose, the $\mathrm{Li}_{x} \mathrm{FePO}_{4}$ reaction product powder was dried and mixed with carbon and binder to produce composite electrodes that were cycled against a lithium metal electrode in Swagelok cells in an organic carbonate electrolyte (LP57). Figure 3 illustrates an example of the galvanostatic removal of lithium from the electrodes prepared with the $\mathrm{Li}_{x} \mathrm{FePO}_{4}$ reaction product obtained using $\mathrm{Na}_{2} \mathrm{SO}_{3}$ as the reducing agent at different reaction times. The capacity associated with the first electrochemical extraction of lithium from the $\mathrm{Li}_{x} \mathrm{FePO}_{4}$ electrode is proportional to the amount of lithium present initially in the electrode, according to the Faradays's law. The lithium content in $\mathrm{Li}_{x} \mathrm{FePO}_{4}$ was obtained taking into account that the as received, fully lithiated $\mathrm{LiFePO}_{4}$ produces an experimental capacity of $160 \mathrm{~mA} \mathrm{~h} \mathrm{~g}^{-1}$. 


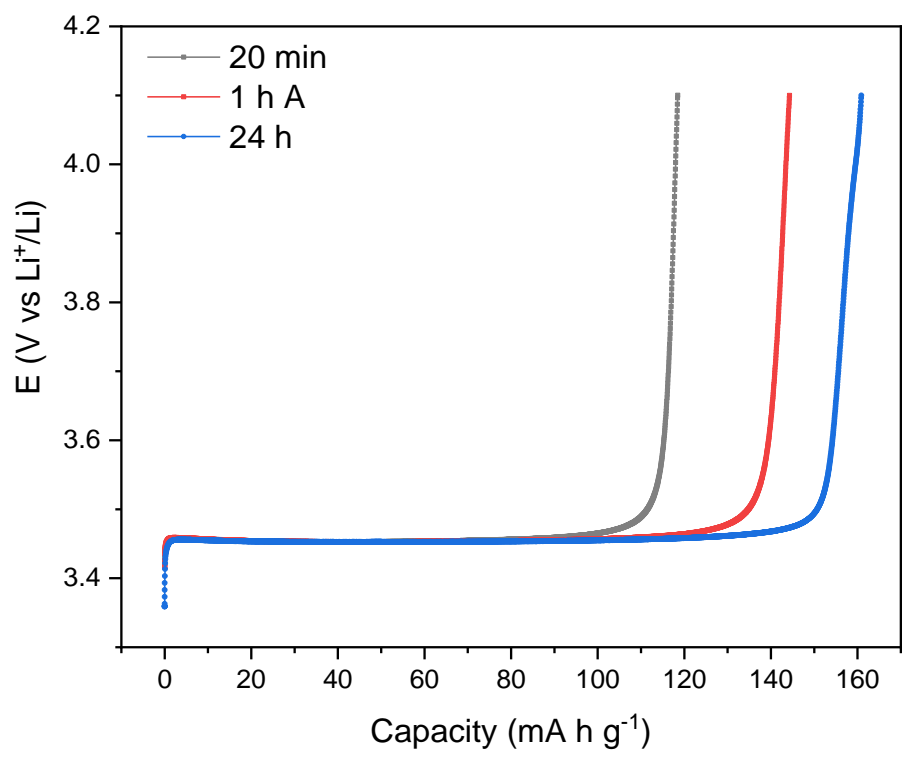

Figure 3. First charge (delithiation) curves of $\mathrm{Li}_{x} \mathrm{FePO}_{4}$ electrodes obtained from the reaction product of $0.375 \mathrm{M} \mathrm{FePO}_{4}$ mixed with $0.75 \mathrm{M} \mathrm{Li}_{2} \mathrm{SO}_{4}$ and $1.5 \mathrm{M} \mathrm{Na}_{2} \mathrm{SO}_{3}$ with different reaction times. Specific current: $17 \mathrm{~mA} \mathrm{~g}^{-1}$ (C-rate of $\left.\mathrm{C} / 10\right)$.

Figure 4 shows examples of the galvanostatic cycling done with electrodes made with the $\mathrm{Li}_{\mathrm{x}} \mathrm{FePO}_{4}$ obtained from the chemical insertion driven by $\mathrm{Na}_{2} \mathrm{~S}_{2} \mathrm{O}_{3}$ or $\mathrm{Na}_{2} \mathrm{SO}_{3}$ after 24 hours of reaction time. The electrochemical data in figure 4a shows that full lithiation of $\mathrm{FePO}_{4}$ was obtained with both reducing agents after 24 hours of reaction time, since the first lithium extraction capacities were the same as in the as received $\mathrm{LiFePO}_{4}$. Further cycling of the samples is shown in figure $4 \mathrm{~b}$, showing good cycling stability, in good agreement with the measurements with the as received $\mathrm{LiFePO}_{4}$. The good electrochemical performance of the samples obtained after the lithium sequestration reaction indicates that the present approach could also be applied for the direct recycling of battery electrodes. ${ }^{41,42}$ For example, the addition of a reducing agent could be used to recover fully lithiated $\mathrm{LiFePO}_{4}$ from a battery containing used $\mathrm{Li}_{x} \mathrm{FePO}_{4}$ electrodes that could have inhomogeneities in the lithium content 
(or state of charge), due to, for example, the presence of regions of the electrode with poor or no contact with the current collector as a result of electrode structural degradation.
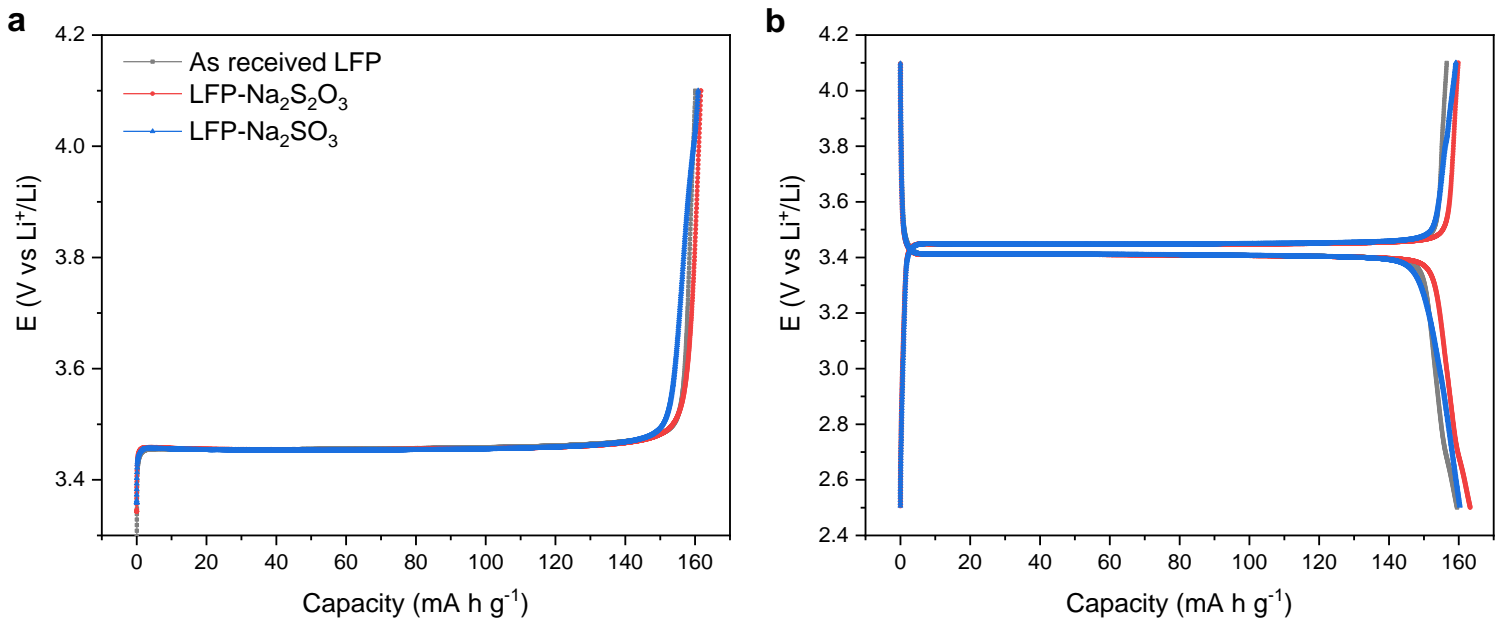

Figure 4. First charge (a) and first discharge and second charge (b) curves of $\mathrm{Li}_{x} \mathrm{FePO}_{4}$ electrodes obtained from the reaction product of $0.375 \mathrm{M} \mathrm{FePO}_{4}$ mixed with $0.75 \mathrm{M} \mathrm{Li}_{2} \mathrm{SO}_{4}$ and $1.5 \mathrm{M} \mathrm{Na}_{2} \mathrm{~S}_{2} \mathrm{O}_{3}$ or $\mathrm{Na}_{2} \mathrm{SO}_{3}$ with 24 hours of reaction time. The curve of the as received $\mathrm{LiFePO}_{4}$ (LFP) is also shown for comparison. Specific current: $17 \mathrm{~mA} \mathrm{~g}^{-1}$ (C-rate of C/10).

\section{Selectivity of lithium sequestration from brines induced by $\mathrm{Na}_{2} \mathrm{SO}_{3}$ or $\mathrm{Na}_{2} \mathrm{~S}_{2} \mathrm{O}_{3}$}

Critical for the success in the implementation of the novel method of lithium production proposed here is a high selectivity for lithium sequestration from solutions containing other ions. Therefore, the selectivity was studied by performing the lithium extraction experiments in solutions mimicking the composition of natural lithium brines, which typically contain sodium, magnesium and potassium in much higher concentration than lithium, see table 2 . Although the electrochemical insertion of sodium into the $\mathrm{FePO}_{4}$ structure obtaining $\mathrm{NaFePO}_{4}$ has been reported by several authors, ${ }^{43-48}$ it is kinetically slower than the formation of $\mathrm{LiFePO}_{4},{ }^{27,48-50}$ and it has been suggested that the introduction of small amounts of lithium 
in the $\mathrm{FePO}_{4}$ structure could block the insertion of sodium ions. ${ }^{51}$ On the other hand, the insertion of magnesium or potassium into $\mathrm{FePO}_{4}$ seems to be prevented. ${ }^{27}$ In order to assess the applicability of the new reducing agent proposed here for commercial applications, two artificial brines were used with similar compositions to those found in lithium reserves in Central Altiplano (Bolivia). ${ }^{40}$

Figure 5 shows the XRD patterns of the solids obtained by reaction of $\mathrm{FePO}_{4}$ in brines in the presence of $0.3 \mathrm{M} \mathrm{Na}_{2} \mathrm{SO}_{3}$ after 24 hours of reaction. The characteristic peaks of the olivine $\mathrm{LiFePO}_{4}$ structure were the only peaks observed for both artificial brine compositions, indicative of the complete chemical insertion of lithium ions forming $\mathrm{LiFePO}_{4}$ only. The insertion of $\mathrm{Na}^{+}$into $\mathrm{FePO}_{4}$ would produce characteristic diffraction peaks associated to olivine $\mathrm{NaFePO}_{4},{ }^{44}$ which are not observed experimentally. The insertion of any other cation in the $\mathrm{FePO}_{4}$ structure, including the insertion of protons, would also produce the appearance of diffraction peaks at different reflection positions, ${ }^{52}$ and therefore, it can be excluded too. Figure 6 shows the results of the electrochemical characterisation, showing the same behavior as the as-received $\mathrm{LiFePO}_{4}$ sample, which again confirms the formation of fully lithiated $\mathrm{LiFePO}_{4}$ as the reaction product. Similar results were previously reported using the same experimental conditions but with $\mathrm{Na}_{2} \mathrm{~S}_{2} \mathrm{O}_{3}$ as reducing agent. ${ }^{30}$ 


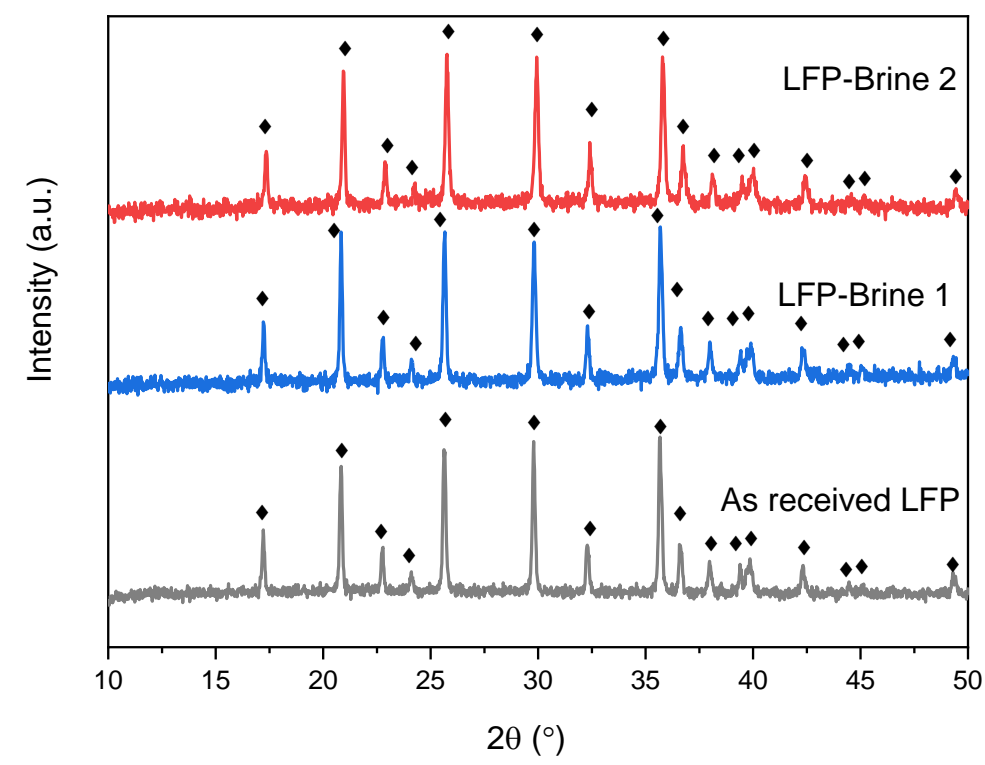

Figure 5. XRD patterns of the $\mathrm{Li}_{x} \mathrm{FePO}_{4}$ solid powder obtained from the reaction of $\mathrm{FePO}_{4}$ in brines with $0.3 \mathrm{M} \mathrm{Na}_{2} \mathrm{SO}_{3}$ after 24 hours of reaction. The diffractograms of the as received $\mathrm{LiFePO}_{4}$ (LFP) powder is also shown for comparison.
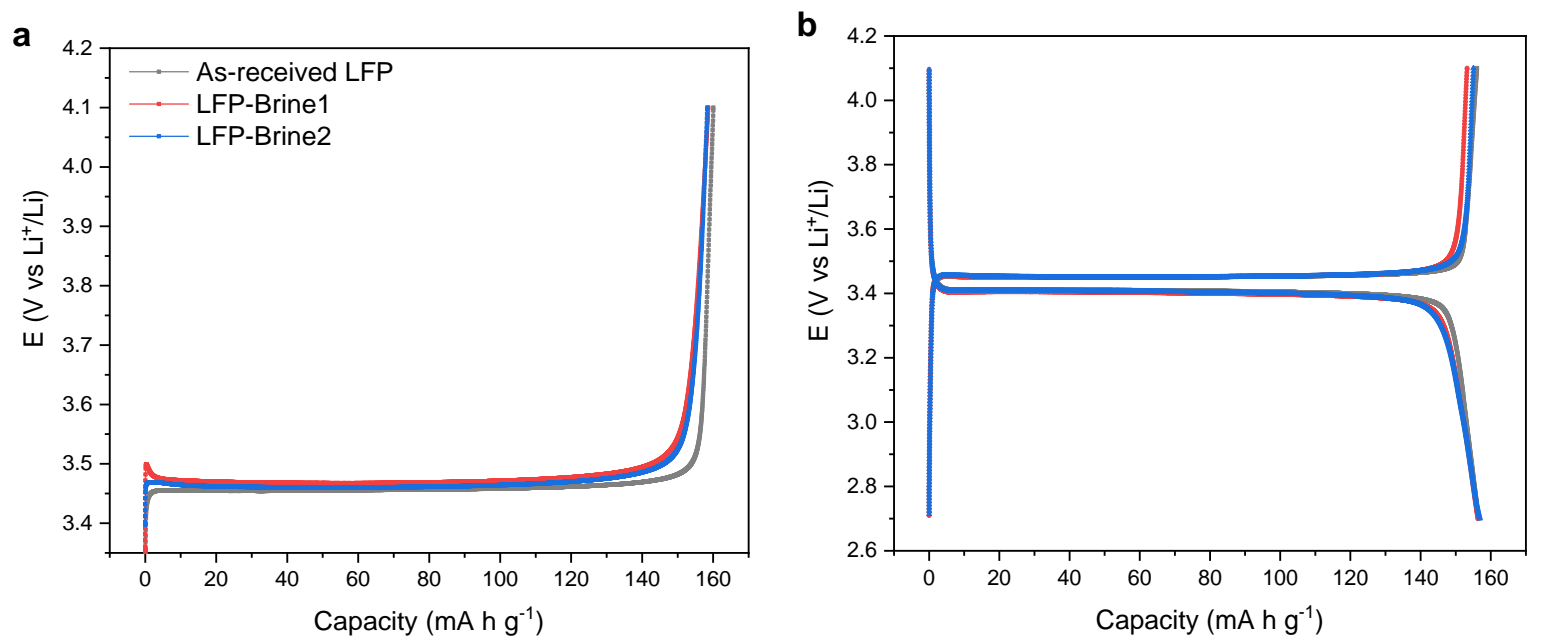

Figure 6. First charge (a) and first discharge and second charge (b) curves of $\mathrm{Li}_{\mathrm{x}} \mathrm{FePO}_{4}$ electrodes obtained from the reaction of $\mathrm{FePO}_{4}$ in brines with $0.3 \mathrm{M} \mathrm{Na}_{2} \mathrm{SO}_{3}$ after 24 hours of reaction. Curves of the as received $\mathrm{LiFePO}_{4}$ (LFP) are also shown for comparison. Specific current: $17 \mathrm{~mA} \mathrm{~g}^{-1}$ (C-rate of $\left.\mathrm{C} / 10\right)$. 
Table 4 compares the results of ICP elemental analysis of the digested $\mathrm{Li}_{\mathrm{x}} \mathrm{FePO}_{4}$ obtained with the two different brines using $\mathrm{Na}_{2} \mathrm{SO}_{3}$ as reducing agent; the results using $\mathrm{Na}_{2} \mathrm{~S}_{2} \mathrm{O}_{3}$ are also included for comparison purposes. The values of $\mathrm{Li}, \mathrm{Na}, \mathrm{K}$ and $\mathrm{Mg}$ uptake reported here have been defined as the amount of ion, in mg, normalized to the mass, in $\mathrm{g}$, of the absorbing material $\left(\mathrm{FePO}_{4}\right)$. For full lithiation of $\mathrm{FePO}_{4}$, forming $\mathrm{LiFePO}_{4}$, the $\mathrm{Li}$ uptake is expected to be $46 \mathrm{mg} \mathrm{g}^{-1}$. Table 4 shows that, for both reducing agents $\left(\mathrm{Na}_{2} \mathrm{SO}_{3}\right.$ and $\left.\mathrm{Na}_{2} \mathrm{~S}_{2} \mathrm{O}_{3}\right)$, the $\mathrm{Li}$ update is indeed close to $46 \mathrm{mg} \mathrm{g}^{-1}$. Furthermore, it is observed that the uptake of other cations is very small, thus demonstrating the high selectivity for lithium.

From the ICP results, it is useful to calculate the molar ratio of lithium ion and other cations $\left(\mathrm{M}=\mathrm{Na}^{+}, \mathrm{K}^{+}\right.$or $\left.\mathrm{Mg}^{2+}\right)$ in the solid $\left(\left[\mathrm{Li}^{+}\right]_{\text {solid: }}[\mathrm{M}]_{\text {solid, }}\right.$, see values in table 4). This can, then, be compared to the molar ratio of lithium and other cations in solution $\left(\left[\mathrm{Li}^{+}\right]_{\text {solution }}:[\mathrm{M}]_{\text {solution, }}\right.$ see table 4). Clearly, lithium is a minority component in solution (that is, in the artificial brines), because the values of $\left[\mathrm{Li}^{+}\right]_{\text {solution: }}[\mathrm{M}]_{\text {solution }}$ are very small. But then lithium becomes the majority component in the solid (that is, in $\mathrm{Li}_{\mathrm{x}} \mathrm{FePO}_{4}$ ) because the values of $\left[\mathrm{Li}^{+}\right]_{\text {solid }}:[\mathrm{M}]_{\text {solid }}$ are very high. In order to quantify this change in relative abundance of $\mathrm{Li}$ with respect to other cations in the solid with respect to the solution, and following our previous work, ${ }^{30}$ we have defined the lithium selectivity as the enhancement of the lithium concentration over that of other cations in the solid with respect to the solution:

Lithium selectivity $=\frac{\left[\mathrm{Li}^{+}\right]_{\text {solid }}:[\mathrm{M}]_{\text {solid }}}{\left[\mathrm{Li}^{+}\right]_{\text {solution }}:[\mathrm{M}]_{\text {solution }}}$

Table 4 shows that the use of $\mathrm{Na}_{2} \mathrm{SO}_{3}$ produces very high values of lithium selectivity, similar to that with $\mathrm{Na}_{2} \mathrm{~S}_{2} \mathrm{O}_{3}$. While the present ICP measurements were done in aqueous solutions, which prevents the evaluation of proton insertion into $\mathrm{FePO}_{4}$, previous experimental and 
theoretical studies have shown that the insertion of protons or hydrogen into $\mathrm{FePO}_{4}$ is negligible. ${ }^{52,53}$

The ICP results can also be used to calculate the lithium purity in the solid, which equals the uptake of lithium by the solid divided by the sum of the uptakes of all cations. With $\mathrm{Na}_{2} \mathrm{SO}_{3}$, the lithium purity in the solid equals $94 \%$ and $96 \%$ for brines 1 and 2 , whereas for $\mathrm{Na}_{2} \mathrm{~S}_{2} \mathrm{O}_{3}$, it is $90 \%$ and $96 \%$. Thus, it is concluded that very high lithium purities in the solid can be achieved by this method: the values of lithium purity compare well with the lithium purity in the recovery solution reported in previous studies (see table 1). Further improvements in lithium purity could be achieved via the optimization of the process and materials. For instance, the $\mathrm{LiFePO}_{4}$ used in this work has been optimized for battery performance in terms of particle size, carbon coating etc., but the properties required are different for lithium production/recycling applications.

Table 4. Li, Na, K and Mg uptakes and lithium selectivity of samples obtained by the reaction of $\mathrm{FePO}_{4}$ with $\mathrm{Na}_{2} \mathrm{~S}_{2} \mathrm{O}_{3}$ or $\mathrm{Na}_{2} \mathrm{SO}_{3}$ in artificial brines 1 or 2 (see table 2) for 24 hours of reaction time.

\begin{tabular}{|c|c|c|c|c|c|c|}
\hline $\begin{array}{c}\text { Reducing } \\
\text { agent }\end{array}$ & Brine & $\mathbf{M}$ & $\begin{array}{l}\text { Uptake } \\
\left(\mathrm{mg} \mathrm{g}^{-1}\right)\end{array}$ & $\begin{array}{c}{\left[\mathbf{L i}^{+}\right]_{\text {solution }}} \\
{[\mathrm{M}]_{\text {solution }}}\end{array}$ & {$\left[\mathbf{L i}^{+}\right]_{\text {solid }}:[\mathbf{M}]_{\text {solid }}$} & $\begin{array}{l}\text { Lithium } \\
\text { selectivity }\end{array}$ \\
\hline \multirow{8}{*}{$\begin{array}{c}\mathrm{Na}_{2} \mathrm{~S}_{2} \mathrm{O}_{3} \\
\text { ref. }\end{array}$} & \multirow{4}{*}{ Brine 1} & $\mathrm{Li}^{+}$ & 45.7 & & & \\
\hline & & $\mathrm{Na}^{+}$ & 2.5 & $1: 77$ & $61: 1$ & 4700 \\
\hline & & $\mathrm{K}^{+}$ & 1.5 & $1: 3$ & $170: 1$ & 510 \\
\hline & & $\mathrm{Mg}^{2+}$ & 0.8 & $1: 5$ & $200: 1$ & 1000 \\
\hline & \multirow{4}{*}{ Brine 2} & $\mathrm{Li}^{+}$ & 46.4 & & & \\
\hline & & $\mathrm{Na}^{+}$ & 0.4 & $1: 15$ & $370: 1$ & 5550 \\
\hline & & $\mathrm{K}^{+}$ & 1.4 & $1: 3$ & 180:1 & 540 \\
\hline & & $\mathrm{Mg}^{2+}$ & 0.2 & $1: 6.5$ & $870: 1$ & 5600 \\
\hline \multirow{8}{*}{$\mathrm{Na}_{2} \mathrm{SO}_{3}$} & \multirow{4}{*}{ Brine 1} & $\mathrm{Li}^{+}$ & 45.5 & & & \\
\hline & & $\mathrm{Na}^{+}$ & 0.9 & 1:77 & $164: 1$ & 12560 \\
\hline & & $\mathrm{K}^{+}$ & 0.3 & $1: 3$ & $782: 1$ & 2608 \\
\hline & & $\mathrm{Mg}^{2+}$ & 1.9 & $1: 5$ & $84: 1$ & 422 \\
\hline & \multirow{4}{*}{ Brine 2} & $\mathrm{Li}^{+}$ & 44.1 & & & \\
\hline & & $\mathrm{Na}^{+}$ & 0.2 & $1: 15$ & $585: 1$ & 8773 \\
\hline & & $\mathrm{K}^{+}$ & 0.2 & $1: 3$ & 1060:1 & 3181 \\
\hline & & $\mathrm{Mg}^{2+}$ & 1.3 & $1: 6.5$ & 118:1 & 765 \\
\hline
\end{tabular}




\section{CONCLUSIONS}

$\mathrm{Na}_{2} \mathrm{SO}_{3}$ is shown to be an advantageous reducing reagent to drive the selective sequestration of lithium from natural brines into a $\mathrm{FePO}_{4}$ host battery material, for applications in an alternative and sustainable method of lithium production, as illustrated in figure 1 . The kinetics of the lithium sequestration reaction are found to be fast, since full lithiation is achieved in one hour in $1.5 \mathrm{M} \mathrm{Na}_{2} \mathrm{SO}_{3}$ solutions. The selectivity of the lithium sequestration reaction is found to be outstanding, since in natural brine solutions containing up to 60-fold excess of sodium, 6-fold excess of magnesium and 3-fold excess of potassium, the amount of lithium inserted per gram of solid absorbant is ca. $45 \mathrm{mg} / \mathrm{g}$ whereas the uptakes of sodium, potassium and magnesium were below $0.9,0.3$ and $1.9 \mathrm{mg} / \mathrm{g}$, respectively. Consequently, the kinetics and selectivity of the lithium sequestration reactions are comparable to those

previously reported using $\mathrm{Na}_{2} \mathrm{~S}_{2} \mathrm{O}_{3}$ as reducing agent. ${ }^{30}$ However, $\mathrm{Na}_{2} \mathrm{SO}_{3}$ has advantages in terms of lower cost, reaction stoichiometry that involves less consumption of reagent, nontoxicity and formation of an innocuous reaction product $\left(\mathrm{Na}_{2} \mathrm{SO}_{4}\right)$.

\section{Acknowledgments}

Profs. John R. Owen, Phil N. Bartlett, Derek Pletcher, Andrew L. Hector, Ernesto Calvo and Victoria Flexer are gratefully acknowledged for fruitful scientific discussions and Prof. Andrew L. Hector is also acknowledged for his help in the preparation of Figure 1. Financial support given to the project "A highly versatile selective approach for lithium production" by the Royal Society (IC170232) is also acknowledged, and NGA thanks the EPSRC for an early career fellowship (EP/N024303/1). The data for this article are available from the University of Southampton at https://doi.org/10.5258/SOTON/D1235. 


\section{References:}

(1) Tarascon, J. M. Is Lithium the New Gold? Nature Chemistry. 2010, 2, 510, DOI 10.1038/nchem.680.

(2) Olivetti, E. A.; Ceder, G.; Gaustad, G. G.; Fu, X. Lithium-Ion Battery Supply Chain Considerations: Analysis of Potential Bottlenecks in Critical Metals. Joule. 2017, 1 (2), 229-243, DOI 10.1016/j.joule.2017.08.019.

(3) Barnhart, C. J.; Benson, S. M. On the Importance of Reducing the Energetic and Material Demands of Electrical Energy Storage. Energy Environ. Sci. 2013, 6 (4), 1083-1092, DOI 10.1039/c3ee24040a.

(4) Wadia, C.; Albertus, P.; Srinivasan, V. Resource Constraints on the Battery Energy Storage Potential for Grid and Transportation Applications. J. Power Sources 2011, 196 (3), 1593-1598, DOI 10.1016/j.jpowsour.2010.08.056.

(5) Kavanagh, L.; Keohane, J.; Cabellos, G. G.; Lloyd, A.; Cleary, J. Global Lithium Sources-Industrial Use and Future in the Electric Vehicle Industry: A Review. Resources 2018, 7 (3), 57, DOI 10.3390/resources7030057.

(6) Flexer, V.; Baspineiro, C. F.; Galli, C. I. Lithium Recovery from Brines: A Vital Raw Material for Green Energies with a Potential Environmental Impact in Its Mining and Processing. Science of the Total Environment. 2018, 639, 1188-1204, DOI 10.1016/j.scitotenv.2018.05.223.

(7) Liu, G.; Zhao, Z.; Ghahreman, A. Novel Approaches for Lithium Extraction from SaltLake Brines: A Review. Hydrometallurgy 2019, 187, 81-100, DOI 10.1016/j.hydromet.2019.05.005.

(8) Swain, B. Recovery and Recycling of Lithium: A Review. Separation and Purification Technology. 2017, 172, 388-403, DOI 10.1016/j.seppur.2016.08.031.

(9) Song, J. F.; Nghiem, L. D.; Li, X.-M.; He, T. Lithium Extraction from Chinese SaltLake Brines: Opportunities, Challenges, and Future Outlook. Environ. Sci. Water Res. Technol 2017, 3, 593-597, DOI 10.1039/c7ew00020k.

(10) Kanoh, H.; Ooi, K.; Miyai, Y.; Katoh, S. Electrochemical Recovery of Lithium Ions in the Aqueous Phase. Sep. Sci. Technol. 1993, 28, 643-651, DOI 10.1080/01496399308019512.

(11) Lee, J.; Yu, S. H.; Kim, C.; Sung, Y. E.; Yoon, J. Highly Selective Lithium Recovery from Brine Using a $\lambda-\mathrm{MnO}_{2}-\mathrm{Ag}$ Battery. Phys. Chem. Chem. Phys. 2013, 15 (20), 7690-7695, DOI 10.1039/c3cp50919b.

(12) Kim, S.; Lee, J.; Kang, J. S.; Jo, K.; Kim, S.; Sung, Y. E.; Yoon, J. Lithium Recovery from Brine Using a $\lambda-\mathrm{MnO}_{2} /$ Activated Carbon Hybrid Supercapacitor System. Chemosphere 2015, 125, 50-56, DOI 10.1016/j.chemosphere.2015.01.024.

(13) Kim, S.; Lee, J.; Kim, S.; Kim, S.; Yoon, J. Electrochemical Lithium Recovery with a $\mathrm{LiMn}_{2} \mathrm{O}_{4}$-Zinc Battery System Using Zinc as a Negative Electrode. Energy Technol. 2018, 6 (2), 340-344, DOI 10.1002/ente.201700488.

(14) Kim, S.; Joo, H.; Moon, T.; Kim, S. H.; Yoon, J. Rapid and Selective Lithium 
Recovery from Desalination Brine Using an Electrochemical System. Environ. Sci. Process. Impacts 2019, 21 (4), 667-676, DOI 10.1039/c8em00498f.

(15) Missoni, L. L.; Marchini, F.; Pozo, M. Del; Calvo, E. J. A LiMn ${ }_{2} \mathrm{O}_{4}-$ Polypyrrole System for the Extraction of $\mathrm{LiCl}$ from Natural Brine. J. Electrochem. Soc. 2016, 163 (9), A1898-A1902, DOI 10.1149/2.0591609jes.

(16) Trócoli, R.; Erinmwingbovo, C.; La Mantia, F. Optimized Lithium Recovery from Brines by Using an Electrochemical Ion-Pumping Process Based on $\lambda-\mathrm{MnO}_{2}$ and Nickel Hexacyanoferrate. ChemElectroChem 2017, 4 (1), 143-149, DOI 10.1002/celc.201600509.

(17) Du, X.; Guan, G.; Li, X.; Jagadale, A. D.; Ma, X.; Wang, Z.; Hao, X.; Abudula, A. A Novel Electroactive $\lambda-\mathrm{MnO}_{2} / \mathrm{PPy} / \mathrm{PSS}$ Core-Shell Nanorod Coated Electrode for Selective Recovery of Lithium Ions at Low Concentration. J. Mater. Chem. A 2016, 4 (36), 13989-13996, DOI 10.1039/c6ta05985f.

(18) Zhao, M. Y.; Ji, Z. Y.; Zhang, Y. G.; Guo, Z. Y.; Zhao, Y. Y.; Liu, J.; Yuan, J. S. Study on Lithium Extraction from Brines Based on $\mathrm{LiMn}_{2} \mathrm{O}_{4} / \mathrm{Li}_{1-\mathrm{x}} \mathrm{Mn}_{2} \mathrm{O}_{4}$ by Electrochemical Method. Electrochim. Acta 2017, 252, 350-361, DOI 10.1016/j.electacta.2017.08.178.

(19) Xu, X.; Zhou, Y.; Feng, Z.; Kahn, N. U.; Haq Khan, Z. U.; Tang, Y.; Sun, Y.; Wan, P.; Chen, Y.; Fan, M. A Self-Supported $\lambda-\mathrm{MnO}_{2}$ Film Electrode Used for Electrochemical Lithium Recovery from Brines. Chempluschem 2018, 83 (6), 521-528, DOI 10.1002/cplu.201800185.

(20) Zhao, A.; Liu, J.; Ai, X.; Yang, H.; Cao, Y. Highly Selective and Pollution-Free Electrochemical Extraction of Lithium by a Polyaniline $/ \mathrm{Li}_{\mathrm{x}} \mathrm{Mn}_{2} \mathrm{O}_{4}$ Cell. ChemSusChem 2019, 12 (7), 1361-1367, DOI 10.1002/cssc.201803045.

(21) Liu, D. F.; Sun, S. Y.; Yu, J. G. Electrochemical and Adsorption Behaviour of $\mathrm{Li}^{+}$, $\mathrm{Na}^{+}, \mathrm{K}^{+}, \mathrm{Ca}^{2+}$, and $\mathrm{Mg}^{2+}$ in $\mathrm{LiMn}_{2} \mathrm{O}_{4} / \lambda-\mathrm{MnO}_{2}$ Structures. Can. J. Chem. Eng. 2019, 97 (S1), 1589-1595, DOI 10.1002/cjce.23370.

(22) Pasta, M.; Battistel, A.; La Mantia, F. Batteries for Lithium Recovery from Brines. Energy Environ. Sci. 2012, 5 (11), 9487-9491, DOI 10.1039/c2ee22977c.

(23) Trócoli, R.; Battistel, A.; Mantia, F. La. Selectivity of a Lithium-Recovery Process Based on $\mathrm{LiFePO}_{4}$. Chem. - A Eur. J. 2014, 20 (32), 9888-9891, DOI 10.1002/chem.201403535.

(24) Trócoli, R.; Battistel, A.; La Mantia, F. Nickel Hexacyanoferrate as Suitable Alternative to Ag for Electrochemical Lithium Recovery. ChemSusChem 2015, 8 (15), 2514-2519, DOI 10.1002/cssc.201500368.

(25) Zhao, Z.; Si, X.; Liu, X.; He, L.; Liang, X. Li Extraction from High Mg/Li Ratio Brine with $\mathrm{LiFePO}_{4} / \mathrm{FePO}_{4}$ as Electrode Materials. Hydrometallurgy 2013, 133, 75-83, DOI 10.1016/j.hydromet.2012.11.013.

(26) Liu, X.; Chen, X.; Zhao, Z.; Liang, X. Effect of $\mathrm{Na}^{+}$on Li Extraction from Brine Using $\mathrm{LiFePO}_{4} / \mathrm{FePO}_{4}$ Electrodes. Hydrometallurgy 2014, 146, 24-28, DOI 10.1016/j.hydromet.2014.03.010.

(27) He, L.; Xu, W.; Song, Y.; Luo, Y.; Liu, X.; Zhao, Z. New Insights into the Application 
of Lithium-Ion Battery Materials: Selective Extraction of Lithium from Brines via a Rocking-Chair Lithium-Ion Battery System. Glob. Challenges 2018, 2 (2), 1700079, DOI $10.1002 / \mathrm{gch} 2.201700079$.

(28) Lawagon, C. P.; Nisola, G. M.; Cuevas, R. A. I.; Kim, H.; Lee, S. P.; Chung, W. J. $\mathrm{Li}_{1-\mathrm{x}} \mathrm{Ni}_{0.33} \mathrm{Co}_{1 / 3} \mathrm{Mn}_{1 / 3} \mathrm{O}_{2} / \mathrm{Ag}$ for Electrochemical Lithium Recovery from Brine. Chem. Eng. J. 2018, 348, 1000-1011, DOI 10.1016/j.cej.2018.05.030.

(29) Lawagon, C. P.; Nisola, G. M.; Cuevas, R. A. I.; Torrejos, R. E. C.; Kim, H.; Lee, S. P.; Chung, W. J. $\mathrm{Li}_{1-\mathrm{x}} \mathrm{Ni}_{0.5} \mathrm{Mn}_{1.5} \mathrm{O}_{4} / \mathrm{Ag}$ for Electrochemical Lithium Recovery from Brine and Its Optimized Performance via Response Surface Methodology. Sep. Purif. Technol. 2019, 416-426, DOI 10.1016/j.seppur.2018.11.046.

(30) Intaranont, N.; Garcia-Araez, N.; Hector, A. L.; Milton, J. A.; Owen, J. R. Selective Lithium Extraction from Brines by Chemical Reaction with Battery Materials. $J$. Mater. Chem. A 2014, 2 (18), 6374-6377, DOI 10.1039/c4ta01101e.

(31) Handbook of Chemistry and Physics, 100th ed.; Rumble, J. R., Ed.; CRC Press, 2019.

(32) Suhr, M.; Klein, G.; Kourti, I.; Rodrigo Gonzalo, M.; Giner Santonja, G.; Roudier, S.; Delgado Sancho, L.; Institute for Prospective Technological Studies. Best Available Techniques (BAT) Reference Document for the Production of Pulp, Paper and Board; Publications Office, 2015, DOI 10.2791/370629.

(33) United States Environmental Protection Agency. Wastewater Technology Fact Sheet Dechlorination (EPA 832-F-99-062); Office of Water (Washington), 2000.

(34) Chemistry of the Textiles Industry; Carr, C., Ed.; Springer, 1995.

(35) İngeç, T.; Tekin, T. Increasing the Conversion Fraction of Sulfur to Sodium Thiosulfate with the Ultrasound Energy. Korean J. Chem. Eng. 2006, 23 (5), 731-735, DOI 10.1007/BF02705919.

(36) Zheng, X.; Gao, W.; Zhang, X.; He, M.; Lin, X.; Cao, H.; Zhang, Y.; Sun, Z. Spent Lithium-Ion Battery Recycling - Reductive Ammonia Leaching of Metals from Cathode Scrap by Sodium Sulphite. Waste Manag. 2017, 60, 680-688, DOI 10.1016/j.wasman.2016.12.007.

(37) Meng, K.; Cao, Y.; Zhang, B.; Ou, X.; Li, D.-M.; Zhang, J.-F.; Ji, X. Comparison of the Ammoniacal Leaching Behavior of Layered $\mathrm{LiNi}_{\mathrm{x}} \mathrm{Co}_{\mathrm{y}} \mathrm{Mn}_{1-\mathrm{x}-\mathrm{y}} \mathrm{O}_{2}(\mathrm{x}=1 / 3,0.5,0.8)$ Cathode Materials. ACS Sustain. Chem. Eng. 2019, 7, 7750-7759, DOI 10.1021/acssuschemeng.8b06675.

(38) Nair, B.; Elmore, A. R. Final Report on the Safety Assessment of Sodium Sulfite, Potassium Sulfite, Ammonium Sulfite, Sodium Bisulfite, Ammonium Bisulfite, Sodium Metabisulfite and Potassium Metabisulfite 1. Int. J. Toxicol. 2003, 22, 63-88, DOI 10.1080/10915810390239478.

(39) Ramana, C. V.; Mauger, A.; Gendron, F.; Julien, C. M.; Zaghib, K. Study of the LiInsertion/Extraction Process in $\mathrm{LiFePO}_{4} / \mathrm{FePO}_{4}$. J. Power Sources 2009, 187 (2), 555564, DOI 10.1016/J.JPOWSOUR.2008.11.042.

(40) Risacher, F.; Fritz, B. Quaternary Geochemical Evolution of the Salars of Uyuni and Coipasa, Central Altiplano, Bolivia. Chem. Geol. 1991, 90 (3-4), 211-231, DOI 
10.1016/0009-2541(91)90101-V.

(41) Harper, G.; Sommerville, R.; Kendrick, E.; Driscoll, L.; Slater, P.; Stolkin, R.; Walton, A.; Christensen, P.; Heidrich, O.; Lambert, S.; et al. Recycling Lithium-Ion Batteries from Electric Vehicles. Nature 2019, 575, 75, DOI 10.1038/s41586-019-1682-5.

(42) Gaines, L. The Future of Automotive Lithium-Ion Battery Recycling: Charting a Sustainable Course. Sustain. Mater. Technol. 2014, 1, 2-7, DOI 10.1016/j.susmat.2014.10.001.

(43) Sevinc, S.; Tekin, B.; Ata, A.; Morcrette, M.; Perrot, H.; Sel, O.; Demir-Cakan, R. InSitu Tracking of $\mathrm{NaFePO}_{4}$ Formation in Aqueous Electrolytes and Its Electrochemical Performances in Na-Ion/Polysulfide Batteries. J. Power Sources 2019, 55-62, DOI 10.1016/j.jpowsour.2018.11.035.

(44) Moreau, P.; Guyomard, D.; Gaubicher, J.; Boucher, F. Structure and Stability of Sodium Intercalated Phases in Olivine $\mathrm{FePO}_{4}$. Chem. Mater. 2010, 22 (14), 41264128, DOI $10.1021 / \mathrm{cm} 101377 \mathrm{~h}$.

(45) Tang, W.; Song, X.; Du, Y.; Peng, C.; Lin, M.; Xi, S.; Tian, B.; Zheng, J.; Wu, Y.; Pan, F.; et al. High-Performance $\mathrm{NaFePO}_{4}$ Formed by Aqueous Ion-Exchange and Its Mechanism for Advanced Sodium Ion Batteries. J. Mater. Chem. A 2016, 4 (13), 4882-4892, DOI 10.1039/c6ta01111j.

(46) Saracibar, A.; Carrasco, J.; Saurel, D.; Galceran, M.; Acebedo, B.; Anne, H.; Lepoitevin, M.; Rojo, T.; Casas Cabanas, M. Investigation of Sodium InsertionExtraction in Olivine $\mathrm{Na}_{\mathrm{X}} \mathrm{FePO}_{4}(0 \leq \mathrm{x} \leq 1)$ Using First-Principles Calculations. Phys. Chem. Chem. Phys. 2016, 18 (18), 13045-13051, DOI 10.1039/c6cp00762g.

(47) Fernández-Ropero, A. J.; Saurel, D.; Acebedo, B.; Rojo, T.; Casas-Cabanas, M. Electrochemical Characterization of $\mathrm{NaFePO}_{4}$ as Positive Electrode in Aqueous Sodium-Ion Batteries. J. Power Sources 2015, 291, 40-45, DOI 10.1016/j.jpowsour.2015.05.006.

(48) Zhu, Y.; Xu, Y.; Liu, Y.; Luo, C.; Wang, C. Comparison of Electrochemical Performances of Olivine $\mathrm{NaFePO}_{4}$ in Sodium-Ion Batteries and Olivine $\mathrm{LiFePO}_{4}$ in Lithium-Ion Batteries. Nanoscale 2013, 5 (2), 780-787, DOI 10.1039/c2nr32758a.

(49) Ellis, B. L.; Nazar, L. F. Sodium and Sodium-Ion Energy Storage Batteries. Current Opinion in Solid State and Materials Science. August 2012, pp 168-177, DOI 10.1016/j.cossms.2012.04.002.

(50) Nakayama, M.; Yamada, S.; Jalem, R.; Kasuga, T. Density Functional Studies of Olivine-Type $\mathrm{LiFePO}_{4}$ and $\mathrm{NaFePO}_{4}$ as Positive Electrode Materials for Rechargeable Lithium and Sodium Ion Batteries. Solid State Ionics 2016, 286, 40-44, DOI 10.1016/j.ssi.2015.12.019.

(51) Zaghib, K.; Trottier, J.; Hovington, P.; Brochu, F.; Guerfi, A.; Mauger, A.; Julien, C. M. Characterization of Na-Based Phosphate as Electrode Materials for Electrochemical Cells. J. Power Sources 2011, 196 (22), 9612-9617, DOI 10.1016/j.jpowsour.2011.06.061.

(52) Benedek, R.; Thackeray, M. M.; van de Walle, A. Free Energy for Protonation Reaction in Lithium-Ion Battery Cathode Materials. Chem. Mater. 2008, 20 (17), 
5485-5490, DOI 10.1021/cm703042r.

(53) Choi, J.; Alvarez, E.; Arunkumar, T. A.; Manthiram, A. Proton Insertion into Oxide Cathodes during Chemical Delithiation. Electrochem. Solid-State Lett. 2006, 9 (5), A241, DOI 10.1149/1.2184495.

Synopsis: Selective lithium sequestration from natural brines with a battery material using a novel reducing agent, sodium sulphite, as a sustainable new approach for lithium production.

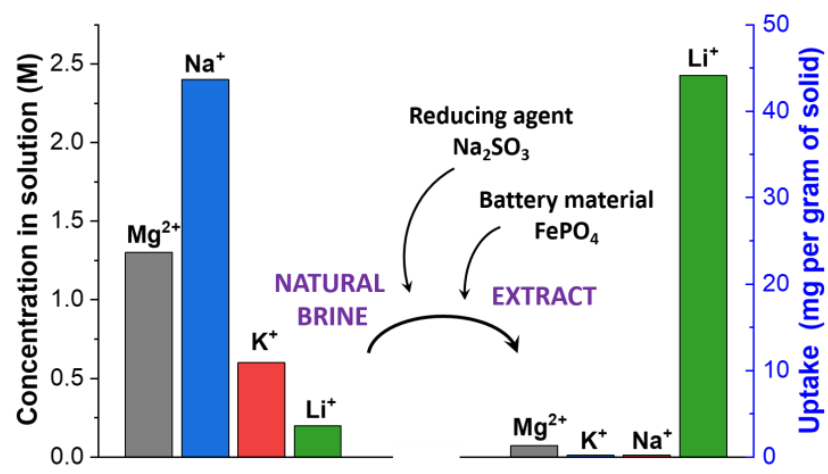

